\title{
Effectiveness of i-SMART Learning Model Using Chemistry Problems Solving in Senior High School to Improve Metacognitive Skills and Students' Conceptual Understanding
}

\author{
Syahmani $^{1}$, Suyono $^{2}$, Z. A. Imam Supardi ${ }^{3}$
}

\author{
Lambung Mangkurat University, Jalan Brigjen H. Hasan Basry Banjarmasin, South Borneo, Indonesia, \\ syahmani_kimia@ulm.ac.id \\ State University of Surabaya, Jalan Lidah Wetan, Surabaya, East Java, Indonesia, suyono@unesa.ac.idr \\ State University of Surabaya, Jalan Lidah Wetan, Surabaya, East Java, Indonesia, zainularifin@unesa.ac.idr
}

Abstract. This study presents i-SMART learning model (Identifying and representing problems, Selecting strategies and plans, Making solutions with monitoring strategies used, Analyzing and evaluating, Reflecting, and Transferring). I-SMART effectiveness in improving students' metacognitive skills and conceptual understanding is analysed. The application of i-SMART learning model in metacognitive activities made concepts easier for students to learn, therefore made it positively responded by students.

Keywords: i-SMART learning model, problem solving, metacognitive skills, conceptual understanding.

\section{Introduction}

The new chemistry concept is inseparable from its chemical representation in the learning process, as a result, students are faced with difficulties such as: (1) the inability to solve chemistry learning problems, especially in the microscopic level (Chittleborough \& Treagust, 2007; Nahum, Mamlok-Naaman, Hofstein, \& Taber, 2010; Rain \& Tytler, 2013; Talanquer, 2011); (2) the inability to understand the chemical concepts and translate the 
problems into mathematical statements (Chandrasegaran, Treagust, \& Waldrip, 2009); and (3) undeveloped students' metacognition and conceptual understanding for solving the problem (Syahmani, Irhasyuarna, \& Kusasi, 2013) .

Indonesia's basis of learning in education revolution is summarized into $4 \mathrm{C}$ (critical thinking, creativity, communication, and collaboration), and correspond with the 21st century learning process grouped into four aspects as follows, creativity, critical thinking, problem solving, and metacognition (Greenstein, 2012; Griffin \& Care, 2015). The problem-solving process also involves the metacognition aspect (Cooper, Sandi-Urena, \& Stevens, 2008; Jacobse \& Harskamp, 2012). When students involve metacognitive skills in solving problems, it maximizes their learning potential (Gama, 2004).

Metacognition is the ability to analyse thinking about thinking (Biryukov, 2003; Mevarech \& Fridkin, 2006), it is also the capacity to control thinking processes through various strategies such as planning, monitoring, and evaluation (Brown, 1987; Cooper \& Sandi-Urena, 2009; Herscovitz, Kaberman, Saar, \& Dori, 2012; Whitebread et al., 2009) which is usually defined as 'cognitions about cognitions', or 'thinking about one's own thinking'. It is categorized into two basic aspects namely, knowledge and regulation metacognitive (Kuhn, 2000). Furthermore, two skills are added namely, representation and transferring technique. Representation competence is the acquisition of meaningful understanding in solving chemistry problems (Carolan, Prain, \& Waldrip, 2008; Rain \& Tytler, 2013). The transfer or application of skills in solving problems improves when students acquire more strategies and knowledge (Billing, 2007; Gama, 2004; Moreno, 2010). Transferring skills are the bases of all creativity, problem solving, and decision making (Sousa, 2012).

Metacognition plays important roles in problem-solving and understanding chemistry concept (Cooper et al., 2008) (Rickey \& Stacy, 2000). It also improves problem-solving skills and cognitive retention capacity (Gama, 2004), as well as an essential component of learning and self-regulation (Efklides, 2011). This motivates students (Muna et al., 2017) and help them in planning, applying, and evaluating their results (Schraw \& Dennison, 1994). Therefore, an alternative method is developed for improving metacognitive skills and students' conceptual understanding of chemistry.

This study aims to analyse the effectiveness of i-SMART model in improving students' metacognitive skills and understanding of chemistry. Focus issues in this study include: 1) the significant increase in metacognitive skills and students' understanding of chemistry before and after the application of i-SMART learning model; 2) the differences in metacognitive skills and students' conceptual understanding between the groups after the application of i-SMART learning model. 


\section{Literature Review}

i-SMART model was designed based on previous researches and findings of metacognition. The developed Syntax for the models was summarized in Table 1.

Table 1

Syntax of i-SMART Model

\begin{tabular}{|c|c|c|c|}
\hline Syntax & Teacher Activities & Student Activities & Metacognitive questioning \\
\hline $\begin{array}{l}\text { Identifying } \\
\text { and repre- } \\
\text { senting } \\
\text { the problem }\end{array}$ & $\begin{array}{l}\text { Bringing up a scientific } \\
\text { problem } \\
\text { Providing students with } \\
\text { guidance in the rep- } \\
\text { resentation and formula- } \\
\text { tion of hypotheses. }\end{array}$ & $\begin{array}{l}\text { Identifying the problem. } \\
\text { Representing them mentally } \\
\text { (or visualizing them with } \\
\text { a computer program and } \\
\text { simulation). }\end{array}$ & $\begin{array}{l}\text { What is the problem about? } \\
\text { What is given in the prob- } \\
\text { lem? } \\
\text { What is representing the } \\
\text { problem? }\end{array}$ \\
\hline $\begin{array}{l}\text { Selecting } \\
\text { strategies } \\
\text { and plans } \\
\end{array}$ & $\begin{array}{l}\text { Asking students to choose } \\
\text { a strategy and develop a } \\
\text { problem-solving plan. }\end{array}$ & $\begin{array}{l}\text { Planning strategies for prob- } \\
\text { lem-solving. }\end{array}$ & $\begin{array}{l}\text { What strategy is suitable for } \\
\text { problem-solving? } \\
\text { Why this strategy is used? }\end{array}$ \\
\hline $\begin{array}{l}\text { Making } \\
\text { solution } \\
\text { with monitor- } \\
\text { ing strategy } \\
\text { use }\end{array}$ & $\begin{array}{l}\text { Guiding students solve } \\
\text { problems. } \\
\text { Monitoring the imple- } \\
\text { mentation of the strategy. } \\
\text { Checking/fixing errors. }\end{array}$ & $\begin{array}{l}\text { Try-revise-check activities. } \\
\text { Developing a metacognitive } \\
\text { skill. }\end{array}$ & $\begin{array}{l}\text { How should the suggested } \\
\text { plan be carried out? }\end{array}$ \\
\hline $\begin{array}{l}\text { Analyzing } \\
\text { and evalu- } \\
\text { ating }\end{array}$ & $\begin{array}{l}\text { Asking students to analyse } \\
\text { data, evaluate the process, } \\
\text { give quizzes, and make } \\
\text { conclusions. }\end{array}$ & $\begin{array}{l}\text { Analyzing data and process } \\
\text { evaluation for problem- } \\
\text { solving. } \\
\text { Checking the solution. }\end{array}$ & $\begin{array}{l}\text { Why is the solution to the } \\
\text { problem? }\end{array}$ \\
\hline Reflecting & $\begin{array}{l}\text { Guiding students to } \\
\text { reflect on learning. }\end{array}$ & $\begin{array}{l}\text { Participating in the reflec- } \\
\text { tion process. } \\
\text { Writing down the addition- } \\
\text { al solution }\end{array}$ & $\begin{array}{l}\text { Does the solution make } \\
\text { sense? } \\
\text { Is there another way to solve } \\
\text { the problem? }\end{array}$ \\
\hline Transferring & $\begin{array}{l}\text { Giving new problems that } \\
\text { are educative to students. }\end{array}$ & $\begin{array}{l}\text { Making an investigation } \\
\text { to tackle problems in new } \\
\text { situations. }\end{array}$ & $\begin{array}{l}\text { Can understanding or skills } \\
\text { be applied to new situations? }\end{array}$ \\
\hline
\end{tabular}

Research findings and the application of i-SMART model were shown in Table 2. 
Table 2

Categorization of the Empirical Papers

\begin{tabular}{|c|c|c|c|c|}
\hline $\begin{array}{l}\text { Author }(s) \\
\text { and year }\end{array}$ & $\begin{array}{l}\text { Scientific skills or } \\
\text { concepts being } \\
\text { assessed }\end{array}$ & $\begin{array}{l}\text { Metacognitive } \\
\text { skills being } \\
\text { assessed }\end{array}$ & $\begin{array}{c}\text { Aspects of metacognition in } \\
\text { the intervention }\end{array}$ & Time \\
\hline $\begin{array}{l}\text { Thomas and } \\
\text { McRobbie } \\
\text { (2001) }\end{array}$ & $\begin{array}{l}\text { Alternative conception } \\
\text { and students' metacog- } \\
\text { nition in chemistry. }\end{array}$ & $\begin{array}{l}\text { Metacognition: } \\
\text { self-concept. }\end{array}$ & $\begin{array}{l}\text { Metacognitive experience in- } \\
\text { terventions. Informing students } \\
\text { about several alternatives for } \\
\text { learning concepts. }\end{array}$ & $\begin{array}{c}12 \\
\text { weeks }\end{array}$ \\
\hline Polya (2004) & $\begin{array}{l}\text { Students' problem- } \\
\text { solving ability in math- } \\
\text { ematics. }\end{array}$ & $\begin{array}{l}\text { Self-directing } \\
\text { question. }\end{array}$ & $\begin{array}{l}\text { Metacognitive representation, } \\
\text { planning, monitoring, and } \\
\text { evaluation. }\end{array}$ & - \\
\hline $\begin{array}{l}\text { Cooper \& } \\
\text { Sandi-Urena } \\
(2009), \text { Sandi- } \\
\text { Urena et al. } \\
\text { (2011) }\end{array}$ & $\begin{array}{l}\text { Assessing metacognitive } \\
\text { skills in domain- specific } \\
\text { context. }\end{array}$ & $\begin{array}{l}\text { Metacognitive } \\
\text { skills. }\end{array}$ & $\begin{array}{l}\text { Promoting metacognitive skills } \\
\text { than the reflection in prob- } \\
\text { lem- solving with Interactive } \\
\text { Multimedia Exercises (IMMEX) } \\
\text { and Metacognitive Activities } \\
\text { Inventory (MCAI). }\end{array}$ & $\begin{array}{c}2.5 \\
\text { weeks }\end{array}$ \\
\hline $\begin{array}{l}\text { Grotzer and } \\
\text { Mittlefehldt } \\
(2012)\end{array}$ & $\begin{array}{l}\text { Conceptual under- } \\
\text { standing and knowledge } \\
\text { transfer. }\end{array}$ & $\begin{array}{l}\text { Metacognitive } \\
\text { monitoring, } \\
\text { evaluation, and } \\
\text { transfer. }\end{array}$ & $\begin{array}{l}\text { Emphasis on the aspects of } \\
\text { monitoring, evaluation, and } \\
\text { transfer. }\end{array}$ & $\begin{array}{c}16 \\
\text { weeks }\end{array}$ \\
\hline $\begin{array}{l}\text { Herscovitz } \\
\text { et al. (2012) }\end{array}$ & $\begin{array}{l}\text { Conceptual under- } \\
\text { standing levels: mac- } \\
\text { roscopic, microscopic, } \\
\text { symbol, and process. }\end{array}$ & $\begin{array}{l}\text { Metacognitive on } \\
\text { chemistry under- } \\
\text { standing levels. }\end{array}$ & $\begin{array}{l}\text { Posing questions based on } \\
\text { metacognitive knowledge and } \\
\text { skills. }\end{array}$ & $\begin{array}{c}4-5 \\
\text { months }\end{array}$ \\
\hline $\begin{array}{l}\text { Thomas } \\
\text { (2013) }\end{array}$ & $\begin{array}{l}\text { Students' understanding in } \\
\text { physics concept. }\end{array}$ & $\begin{array}{l}\text { Metacognitive } \\
\text { orientation and } \\
\text { reflection. }\end{array}$ & $\begin{array}{l}\text { Changing the orientation of a } \\
\text { classroom environment to stim- } \\
\text { ulate the reflection in physics } \\
\text { learning. }\end{array}$ & 6 weeks \\
\hline $\begin{array}{l}\text { Taasoobshira- } \\
\text { zi and Farley } \\
(2013)\end{array}$ & $\begin{array}{l}\text { Students' metacogni- } \\
\text { tion for solving physics } \\
\text { problems. }\end{array}$ & $\begin{array}{l}\text { Metacognitive } \\
\text { knowledge and } \\
\text { skills. }\end{array}$ & $\begin{array}{l}\text { Metacognitive knowledge } \\
\text { (declarative, procedural, and } \\
\text { conditional knowledge) and } \\
\text { skills (planning, monitoring, } \\
\text { evaluation, debugging, and } \\
\text { information management). }\end{array}$ & $\begin{array}{c}12 \\
\text { weeks }\end{array}$ \\
\hline Java (2014) & $\begin{array}{l}\text { The problem-solving } \\
\text { strategy (GEAR) in } \\
\text { mathematics enhances } \\
\text { metacognitive skills. }\end{array}$ & $\begin{array}{l}\text { Metacognitive } \\
\text { skills }\end{array}$ & $\begin{array}{l}\text { Effect of GEAR strategy inter- } \\
\text { vention towards the metacog- } \\
\text { nitive skills of students with } \\
\text { MCAI. }\end{array}$ & 4 weeks \\
\hline Wang (2015) & $\begin{array}{l}\text { Students' construction } \\
\text { of scientific explanations } \\
\text { in inquiry-based biology } \\
\text { activities. }\end{array}$ & $\begin{array}{l}\text { Metacognitive } \\
\text { evaluation }\end{array}$ & $\begin{array}{l}\text { Instructions for completing } \\
\text { self-evaluation using standard } \\
\text { unit ideas. }\end{array}$ & $\begin{array}{c}10 \\
\text { weeks }\end{array}$ \\
\hline
\end{tabular}


The i-SMART model is an alternative instructional method designed to improve metacognition skills and students' conceptual understanding of chemistry. This model was developed to facilitate students' thinking and learning ability during the process of representing problems, planning, choosing strategies, monitoring, evaluating, and knowledge transfer in order to improve cognitive performance in the future. The syntax of i-SMART Model consists six steps as follows: (1) identifying and representing problem; (2) selecting strategies and plans; (3) providing solutions with the strategies; (4) analyzing and evaluating; (5) reflecting; and (6) transferring of the acquired knowledge (Syahmani, Suyono, \& Imam-Supardi, 2017). The i-SMART implementation by teachers requires scaffolding in the form of metacognitive questions to help students systematically solve problems. It was observed that these questions play important roles in making the students' learning process more efficient. For example, questions help students to: (1) activate their pre-knowledge (Osman \& Hannafin, 1994); (2) increase the students' understanding (Kramarski \& Zeichner, 2001); (3) improve their cognitive processes (Kaberman \& Dori, 2009); (4) enhance students'cognition (Conner, 2007; Syahmani, \& Amini, 2019); (5) enhance metacognitive skills (Taylor, Alber, \& Walker, 2002); and (6) create awareness of the problem and improve students' ability to solve them (Sanjaya, Muna, Suharto, \& Syahmani, 2017). This study relevant with research Kaberman \& Dori (2009) guided question posing while using a metacognitive strategy by 12th grade honors chemistry students. Kaberman \& Dori (2009) investigated the ways by which the metacognitive strategy affected students' skills to pose complex questions and to analyze them according to a specially designed taxonomy.

\section{Research Method}

This research was conducted using three classes in different schools, each consisted of 30 students of 11th grade from the science program at senior high school (Banjarmasin, Indonesia). A preliminary and post-test were performed for the classes (groups) with the same level of knowledge and skills. The group pre and post-test model used was designed O1 X O2 for 10 weeks (Fraenkel, Wallen, \& Hyun, 2012). The application of i-SMART learning model helped in developing students' metacognitive skills and conceptual understanding for solving chemistry learning problems. The intervention period takes place on the Chemical Equilibrium learning unit shown in Table 3. 
Table 3

Implementation of i-SMART Learning Model

\begin{tabular}{clc}
\hline Activity & \multicolumn{1}{c}{ Description } & Time \\
\hline A & Pre-test MCAI, MCST, and CUT & Week 1 \\
B & The introduction and modelling of students metacognitive & Week 1 \\
C & Dynamic equilibrium (Actual Problem 1); First class observation & Week 2 \\
D & Design Lab - Homogenous and Heterogeneous equilibrium & Week 2 \\
E & Second class observation & Week 3 \\
F & Equilibrium constant (Actual Problem 2) & Week 4 \\
G & Third class observation & Week 5 \\
H & Quantitative relationship within the equilibrium (Actual Problem 3) & Week 6 \\
I & Design Lab - Equilibrium Shift & Week 7 \\
J & Fourth class observation & Week 8 \\
K & Chemical equilibrium in an industrial process (Actual Problem 4) & Week 9 \\
L & Fifth class observation & Week 10 \\
M & Post-test MCAI, MCST, and CUT & Week 10 \\
\hline
\end{tabular}

The learning process began with pre-test (O1), each student was asked to work on metacognitive skills and conceptual understanding, then fill out a questionnaire of metacognitive activity inventory (MCAI), metacognitive skill test (MCST), and conceptual understanding test (CUT). The reliability of MCAI, MCST, and CUT produced Cronbach's a values of $0.91,0.89$, and 0.86 respectively.

The MCAI questionnaire (modified from Cooper \& Sandi-Urena, 2009) consisted of 35 items and used a 5-point Likert Scale ranging from 1 for strongly disagree to 5 for strongly agree. While the Metacognitive Skill Test (MCST) consisted of 6 questions with each question having 5 indicators including: representing, planning, monitoring, evaluating, and transferring, shown in Table 4, while the assessment rubric was shown in Table 5.

Table 4

Development of the Metacognitive Skills Aspect

\begin{tabular}{lll}
\hline $\begin{array}{c}\text { Aspects of } \\
\text { Metacognitive }\end{array}$ & \multicolumn{1}{c}{ Description } & \multicolumn{1}{c}{ Reference } \\
\hline Representing & $\begin{array}{l}\text { Identifying the problem. } \\
\text { Representing the problem mentally. }\end{array}$ & $\begin{array}{l}\text { Delvecchio (2011), Polya (2004), Kapa (2002), } \\
\text { Cooper \& Sandi-Urena (2009), Panaoura et al. } \\
(2009), \text { Talanquer (2011), Thomas (2013). }\end{array}$ \\
\hline Planning & $\begin{array}{l}\text { Developing a problem-solving plan. } \\
\text { Breaking the problem down, and } \\
\text { Mapping out a solution. }\end{array}$ & $\begin{array}{l}\text { Howard et al.(2000), Kapa (2002), Hart- } \\
\text { man (2001), Polya (2004), Erskine (2009), } \\
\text { Sandi-Urena et al. (2011), Delvecchio (2011). }\end{array}$ \\
\hline Monitoring & Trying, checking, and revising. & $\begin{array}{l}\text { Polya (2004), Hartman (2001); Cooper \& } \\
\text { Sandi-Urena (2009), Delvecchio (2011), } \\
\text { Grotzer and Mittlefehldt (2012). }\end{array}$ \\
\hline
\end{tabular}




\begin{tabular}{lll}
\hline $\begin{array}{c}\text { Aspects of } \\
\text { Metacognitive }\end{array}$ & \multicolumn{1}{c}{ Description } & \multicolumn{1}{c}{ Reference } \\
\hline Evaluating & $\begin{array}{l}\text { Answering the question, and } \\
\text { checking the answer. }\end{array}$ & $\begin{array}{l}\text { Polya (2004), Docktor (2009), Erskine (2010), } \\
\text { Wang (2015), Cooper \&Sandi-Urena (2009), } \\
\text { Delvecchio (2011), Thomas (2013). }\end{array}$ \\
\hline Transferring & $\begin{array}{l}\text { Make an investigation to tackle prob- } \\
\text { lem-solving in a new situation. }\end{array}$ & $\begin{array}{l}\text { Grotzer and Mittlefehldt (2012), MacGregor } \\
(2007), \text { Moreno (2010), Delvecchio (2011). }\end{array}$ \\
\hline
\end{tabular}

Table 5

Rubric for Metacognitive Skill Test assisted by Metacognitive Questioning

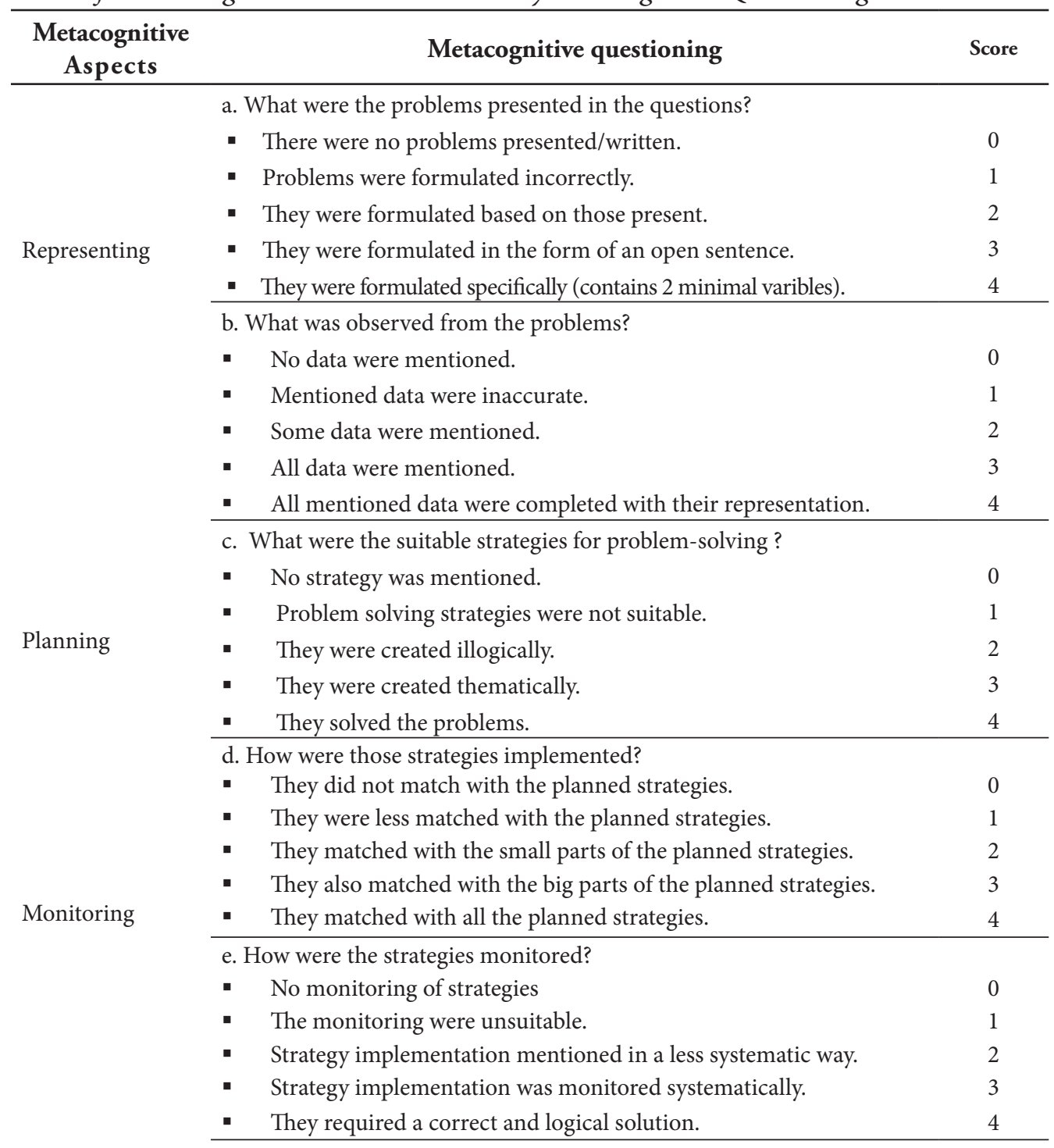




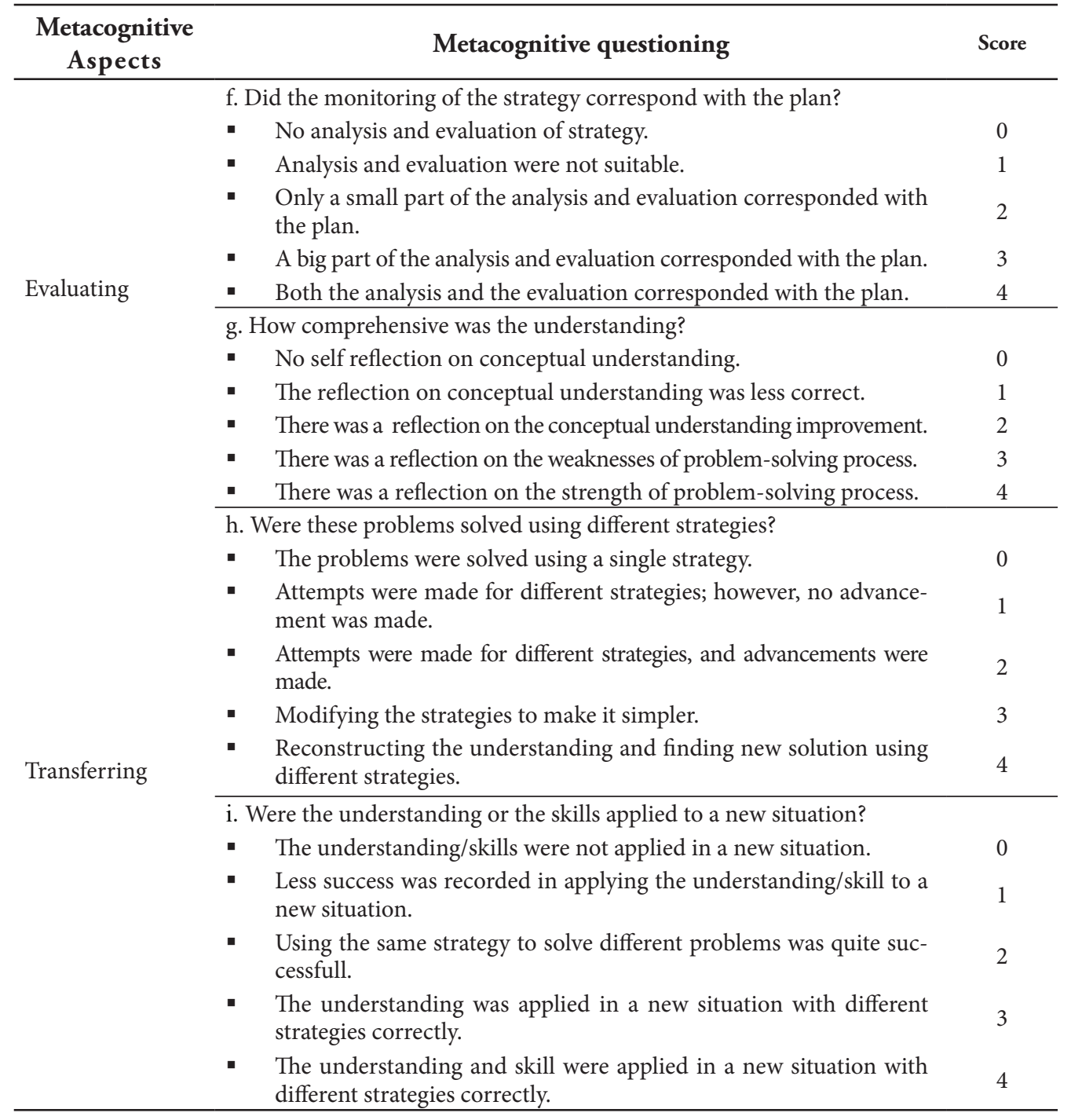

Students' conceptual understanding tests consisted of six indicators adapted from Anderson \& Krathwohl (2001), which included: interpreting, modelling, classifying, comparing, explaining, and concluding. The application of i-SMART model in a group (X) improved students' metacognitive skills and conceptual understanding in each phase of learning. At the end of the study, a post-test (O2) on metacognitive skill was conducted for obtaining the students' score data.

The conceptual understanding test (CUT) consisted of 20 questions of three-tier diagnostic tests. The first tier was multiple questions about chemistry concept being taught, 
the second tier was on the reasons for the answers, and the certainty of their answers. This test was adopted from Arslan, Cigdemoglu, and Moseley (2012).

Statistical data analysis was used in this study, MCAI were analysed descriptively, while MCST and CUT analysis used inferential statistic. To determine the significant improvement after treatment, the pre- and post-test results were statistically tested using paired t-test (when data were in accordance with the normality assumption) or Wilcoxon test (when data did not correspond with the normality assumption) with $\alpha=5 \%$, meanwhile, the rate of increase was calculated using n-gain. The t-test and the Wilcoxon test were used to determine the average value for the pre- and post-test of MCST and CUT. This analysis addressed the first research question on the effect of metacognitive instruction on students' skills and conceptual understanding. The use of t-test or Wilcoxon for analysis depended on the data normality. These analyses were calculated using SPSS (version 23). In addition, a descriptive statistic was also calculated for the MCST and CUT administration (n, M, and SD). Cronbach's Alfa was calculated to determine the internal consistency of MCST and CUT instruments.

Furthermore, the Kruskal-Wallis analysis was used to determine the consistency of the mean score between the MCST and CUT tests. This analysis was adopted since the group 3 data did not correspond with the normality assumption. The results showed that all groups were similar and adequate as the data replication group.

\section{Results and Discussion}

The application of i-SMART learning model in metacognitive activities made concepts easier for students to learn. This model was developed from constructivist learning, information processing, cognitive psychology, conceptual change, and problem-solving theory.

The first phase was supported by Piaget's personal interaction and Talanquer's representation theory. Therefore, individuals actively identify and develop concepts in the form of cognitive conflicts, providing the data in the form of image representation, and experiencing cognitive conflict (Hadjiachilleos, Valanides, \& Angeli, 2013). Students misunderstanding the concept experience conceptual change (Posner, et al., 1982; Carey, 2000), therefore, presenting the concept in disequilibration condition (Kang, 2010; Zhou, 2010).

In the second phase, students were facilitated to prepare and plan for problem-solving (Polya, 2004). The use of learning and planning strategies were effective in improving students' conceptual understanding, problem-solving abilities, and metacognitive skills (Kapa, 2002).

In the third phase, students solved problems with different strategies, and were asked to discuss the experimental results, and provide arguments related to anomalous situations. This allowed interactions among peers in a work group to exchange their ideas 
on the experiment. At this stage, cognitive accommodation was attempted, in order to determine the reliability of the result interpretation of the experiments conducted. The metacognitive orientation was performed by asking questions (such as, what do you mean, why, and how is this possible), in order to provide meaningful understanding.

In the fourth phase, students analysed and evaluated the data obtained. In this stage students' conceptual understanding was built based on Piaget \& Vigotsky's constructivist theory (Blake \& Pope, 2008; Moreno, 2010; Santrock, 2011; Yu, Tsai, \& Wu, 2013) by involving them actively and collaboratively in group work for easy learning (Gagne et al., 2005). Zhou (2010) suggested the use of student learning results obtained from their group work and arguments, as the medium for introducing scientific concepts.

In the fifth phase, students reflected on the understanding and skills they acquired in the learning process. This stage aimed to test the students' competency, which was the basis for evaluating their learning process. They were asked several questions such as, what was the concept condition before and after being instructed, the changes observed, and assuming there was a change, which part of the instructions effected it. To test for metacognition (both in knowledge and skills), questions were asked based on students' preconceptions and new conceptions. When there were differences, what causes these changes and the result status, either positive or not. For students, this becomes the basis for self-reflection on their achievements. The addition of reflection is based on the theory of Arends \& Kilcher (2011) and Fry et al. (2009) which stated that the importance of reflection activities was for follow-up effort after the learning process.

In the sixth phase, students made use of their knowledge and confirmed the ideas they had acquired in the new situation. This stage was supported by the transfer theory from Moreno and Sousa, which stated that students with strategies and knowledge, were more capable of transferring their experience to a new situation. Therefore, utilizing their knowledge (new concepts) in different physical conditions, and testing its usefulness. In this section, teachers also convinced students that the new concept was understandable, equitable, and beneficial with the metacognitive strategies (She, 2002).

The results of students' conceptual skills and understanding were shown in Table 6. 
Table 6

The n-gain Metacognitive Skills and Students' Conceptual Understanding for All Groups

\begin{tabular}{lcccccccc}
\multirow{2}{*}{$\begin{array}{c}\text { Aspect of } \\
\text { assessment }\end{array}$} & Groups & $\mathbf{N}$ & \multicolumn{2}{c}{ Average of pre-test } & \multicolumn{2}{c}{ Average of post-test } & & \multicolumn{2}{c}{$\begin{array}{c}\boldsymbol{n} \text {-gain } \\
\text { category }\end{array}$} \\
\cline { 3 - 7 } & & & $\mathbf{N 1}$ & $\mathbf{K 1}$ & $\mathbf{N 2}$ & $\mathbf{K 2}$ & & \\
\hline Metacognitive & 1 & 30 & 18.89 & Less & 79.26 & Good & 0.74 & High \\
skills & 2 & 30 & 19.07 & Less & 82.50 & Very good & 0.78 & High \\
& 3 & 30 & 13.15 & Less & 75.56 & Good & 0.72 & High \\
\hline Conceptual & 1 & 30 & 23.00 & Less & 78.17 & Good & 0.72 & High \\
understand- & 2 & 30 & 13.80 & Less & 88.50 & Very good & 0.88 & High \\
ing & 3 & 30 & 14.67 & Less & 77.00 & Good & 0.72 & High \\
\hline
\end{tabular}

Note. Group 1 (SMAN1XI-MIA5), Group 2 (SMAN2 XI-MIA6), Group 3 (SMAN7 XI-MIA7), N1 and N2 = pretest and post-test scores;

K1, K2 = Performance categories; $80-100=$ very good, $66-79=$ good, $56-65=$ enough, $<56=$ less; $<\mathrm{g}>=\mathrm{n}$-gain coefficient.

The results of extensive trials based on Table 6 showed that most students possessed good metacognition skills and conceptual understanding with an average score of n-gain $>0.70$, therefore, they were classified with the high n-gain category. The results of normality and homogeneity tests were presented in Tables 7 and 8.

Table 7

The Normalized Test of Metacognitive Skills and Students'Conceptual Understanding for All Groups

\begin{tabular}{|c|c|c|c|c|c|c|c|c|c|c|}
\hline \multirow{3}{*}{ ڤั) } & \multirow{3}{*}{ Test } & \multirow{3}{*}{$\mathbf{N}$} & \multicolumn{8}{|c|}{ Kolmogorov-Smirnov ${ }^{a}$} \\
\hline & & & \multicolumn{3}{|c|}{ Metacognitive skills } & \multicolumn{5}{|c|}{ Conceptual understanding } \\
\hline & & & Mean & Statistic & $\begin{array}{l}\text { Asymp. } \\
\text { Sig. } \\
\text { (2-tailed) }\end{array}$ & $\begin{array}{c}\text { Normal } \\
\text { distri- } \\
\text { bution }\end{array}$ & Mean & $\begin{array}{l}\text { Statis- } \\
\text { tic }\end{array}$ & $\begin{array}{c}\text { Asymp. } \\
\text { Sig. } \\
\text { (2-tailed) }\end{array}$ & $\begin{array}{c}\text { Normal } \\
\text { distri- } \\
\text { bution }\end{array}$ \\
\hline \multirow[t]{2}{*}{1} & Pre-test & 30 & 18.89 & 0.161 & $0.061^{\star}$ & Yes & 23.00 & 0.143 & $0.121^{\star}$ & Yes \\
\hline & Post-test & 30 & 79.26 & 0.909 & $0.054^{b^{*}}$ & Yes & 78.17 & 0.142 & $0.125^{*}$ & Yes \\
\hline \multirow[t]{2}{*}{2} & Pre-test & 30 & 19.07 & 0.175 & 0.020 & No & 13.80 & 0.181 & 0.014 & No \\
\hline & Post-test & 30 & 82.50 & 0.143 & $0.122^{*}$ & Yes & 88.50 & 0.192 & 0.006 & No \\
\hline \multirow[t]{2}{*}{3} & Pre-test & 30 & 13.15 & 0.174 & 0.021 & No & 14.67 & 0.208 & 0.002 & No \\
\hline & Post-test & 30 & 75.56 & 0.250 & 0.000 & No & 77.00 & 0.157 & $0.058^{\star}$ & Yes \\
\hline
\end{tabular}

Note. Group 1 (SMAN1 XI-MIA5); Group 2 (SMAN2 XI-MIA6); Group 3 (SMAN7 XI-MIA7)

${ }^{a}$ Lilliefors Significance Correction; ${ }^{b}$ Shapiro-Wilk normal distribution; ${ }^{\star}$ ) Sig. $p>0.05$ 
Table 8

The Homogeneity Test of Metacognitive Skills and Students' Conceptual Understanding for All Groups

\begin{tabular}{|c|c|c|c|c|c|c|c|c|c|c|}
\hline \multirow{3}{*}{ 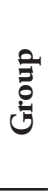 } & \multirow{3}{*}{ Test } & \multirow{3}{*}{$\mathbf{N}$} & \multicolumn{8}{|c|}{ Levene } \\
\hline & & & \multicolumn{4}{|c|}{ Metacognitive skills } & \multicolumn{4}{|c|}{ Conceptual understanding } \\
\hline & & & Mean & Statistic & $\underset{\text { (2-tailed) }}{p \text { sig. }}$ & $\begin{array}{c}\text { Homo- } \\
\text { gen }\end{array}$ & Mean & $\begin{array}{l}\text { Statis- } \\
\text { tic }\end{array}$ & $\underset{\text { (2-tailed) }}{p \text { sig. }}$ & $\begin{array}{c}\text { Homo- } \\
\text { gen }\end{array}$ \\
\hline \multirow[t]{2}{*}{1} & Pre-test & 30 & 18.89 & 0.481 & $0.749^{\star}$ & Yes & 23.00 & 0.251 & $0.953^{*}$ & Yes \\
\hline & Post-test & 30 & 79.26 & 0.934 & $0.477^{\star}$ & Yes & 78.17 & 1.750 & $0.167^{\star}$ & Yes \\
\hline \multirow[t]{2}{*}{2} & Pre-test & 30 & 19.07 & 2.558 & $0.051^{*}$ & Yes & 13.80 & 1.991 & $0.142^{*}$ & Yes \\
\hline & Post-test & 30 & 82.50 & 1.479 & $0.233^{*}$ & Yes & 88.50 & 1.067 & $0.405^{*}$ & Yes \\
\hline \multirow[t]{2}{*}{3} & Pre-test & 30 & 13.15 & 1.592 & $0.220^{*}$ & Yes & 14.67 & 2.763 & 0.037 & No \\
\hline & Post-test & 30 & 75.56 & 2.774 & 0.043 & No & 77.00 & 0.618 & $0.688^{*}$ & Yes \\
\hline
\end{tabular}

Tables 7 and 8 showed that the test data from metacognitive skills and students' conceptual understanding were evenly distributed in group-1. Meanwhile, group-2 and group-3 had either pre- or post-test data that were not evenly distributed (Sig. <0.05). The homogeneity test showed that data from three groups were all homogeneous (Sig.> 0.05). Therefore, the impact of i-SMART model in group-1 was tested using paired t-tests. For students from group-2 and group-3, data were tested using the Wilcoxon test, since their data were not evenly distributed.

Table 9

Paired t-test and Wilcoxon Test of Metacognitive Skills and Students' Conceptual Understanding

Paired t-test

Wilcoxon test

\begin{tabular}{|c|c|c|c|c|c|c|c|c|c|c|c|}
\hline $\begin{array}{c}\text { Aspect of } \\
\text { assessment }\end{array}$ & Group & $\mathbf{N}$ & Mean & $\begin{array}{c}\text { Std. error } \\
\text { mean }\end{array}$ & $\mathbf{T}$ & df & $\begin{array}{c}p \\
\text { (Sig.) }\end{array}$ & $\mathrm{Z}$ & $\begin{array}{c}\text { Asymp. } \\
\text { Sig. (2-tailed) }\end{array}$ & $\begin{array}{c}\text { p } \\
(\text { Sig. })\end{array}$ & Conclusion \\
\hline \multirow{3}{*}{$\begin{array}{l}\text { Metacognitive } \\
\text { skills }\end{array}$} & 1 & 30 & -60.376 & 1.153 & -52.380 & 29 & $0.000^{*}$ & - & - & - & Ho rejected \\
\hline & 2 & 30 & & & & & & -4.794 & $0.000^{* *}$ & $0.000^{* * *}$ & Ho rejected \\
\hline & 3 & 30 & & & & & & -4.804 & $0.000^{* *}$ & $0.000^{* * *}$ & Ho rejected \\
\hline \multirow{3}{*}{$\begin{array}{l}\text { Conceptual } \\
\text { understand- } \\
\text { ing }\end{array}$} & 1 & 30 & -53.500 & 2.064 & -25.916 & 29 & $0.000^{*}$ & - & - & - & Ho rejected \\
\hline & 2 & 30 & & & & & & -4.820 & $0.000^{* *}$ & $0.000^{\star * *}$ & Ho rejected \\
\hline & 3 & 30 & & & & & & -4.791 & $0.000^{* *}$ & $0.000^{\star * *}$ & Ho rejected \\
\hline
\end{tabular}

Note. Group 1 (SMAN1 XI-MIA5); Group 2 (SMAN2 XI-MIA6); Group 3 (SMAN7 XI-MIA7);

${ }^{\star}$ Pair-Samples T-Test $p<0.05$ (2-tailed), ${ }^{* *}$ Wilcoxon Signed Ranks Test: $p<0.05$ (2-tailed), ${ }^{* * *}$ Monte Carlo: $p<0.05$ (1-tailed) 
Table 9 showed that the students' metacognitive skills and conceptual understanding had increased in the three groups. Group 1 p-value (Sig. 2-tailed) $<0.05$, while for groups 2 and 3 Monte Carlo (Sig. 1-tailed) $<0.05$, in addition, Ho was rejected. This means that students' metacognitive skills and conceptual understanding in the three groups during the post-test were significantly higher than the pre-test learning, after i-SMART learning model had been applied.

The increase in n-gain between the three groups after the application of i-SMART model was checked through the mean similarity test of n-gain (Table 11). Kruskal-Wallis test was conducted to determine the significant differences between the three groups as presented in Table 10.

Table 10

Result of Kruskal-Wallis Test on Students' Metacognitive Skill and Conceptual Understanding

\begin{tabular}{|c|c|c|c|c|c|c|c|c|c|c|c|}
\hline \multirow{2}{*}{$\begin{array}{l}\text { : } \\
\text { हैं }\end{array}$} & \multirow[b]{2}{*}{$\mathbf{N}$} & \multicolumn{5}{|c|}{ Metacognitive skills } & \multicolumn{5}{|c|}{ Conceptual understanding } \\
\hline & & Mean & $\begin{array}{l}\text { Chi- } \\
\text { Square }\end{array}$ & $d f$ & p (Sig.) & Conclusion & Mean & $\begin{array}{l}\text { Chi- } \\
\text { Square }\end{array}$ & $d f$ & p (Sig.) & Conclusion \\
\hline 1 & 30 & 79.26 & 9.097 & 7.0 & $0.206^{*}$ & Ho accepted & 78.17 & 5.254 & 7.0 & $0.695^{*}$ & Ho accepted \\
\hline 2 & 30 & 82.50 & 11.559 & 9.0 & $0.181^{\star}$ & Ho accepted & 88.50 & 6.034 & 8.0 & $0.720^{*}$ & Ho accepted \\
\hline 3 & 30 & 75.56 & 13.917 & 9.0 & $0.059^{*}$ & Ho accepted & 77.00 & 6.438 & 8.0 & $0.669^{*}$ & Ho accepted \\
\hline
\end{tabular}

Table 10 showed that p-value (Sig.) of students' metacognition skills for the three groups were $>0.05$, in order for Ho hypothesis to be accepted. Therefore, no significant difference in n-gain of students' metacognitive skills between the three groups, however, the application of i-SMART model improved students' metacognitive skills placing n-gain at high criteria. This corresponded with p-value $>0.05$ (Sig.) of students' conceptual understanding for the three groups, in order for Ho hypothesis to be accepted. This results showed that the i-SMART model improved students' metacognition skills with high consistency as compared between the different groups.

\section{Aspects of Metacognition Skills and Students' Understanding}

The results of n-gain test for metacognitive skills and students' conceptual understanding were presented in Table 11. 
Table 11

$N$-gain Result of Students' Metacognitive Skills and Conceptual Understanding

\begin{tabular}{|c|c|c|c|c|c|c|c|}
\hline \multirow{2}{*}{$\begin{array}{c}\text { Aspect of } \\
\text { metacognitive } \\
\text { skills }\end{array}$} & \multicolumn{3}{|c|}{$N$-gain } & \multirow{2}{*}{$\begin{array}{c}\text { Aspect of } \\
\text { conceptual } \\
\text { understanding }\end{array}$} & \multicolumn{3}{|c|}{$N$-gain } \\
\hline & Group 1 & Group 2 & Group 3 & & Group 1 & Group 2 & Group 3 \\
\hline Representing & $0.79(\mathrm{~h})$ & $0.86(\mathrm{~h})$ & $0.69(\mathrm{~m})$ & Explaining & $0.65(\mathrm{~m})$ & $0.96(\mathrm{~h})$ & $0.77(\mathrm{~h})$ \\
\hline Planning & $0.78(\mathrm{~h})$ & $0.89(\mathrm{~h})$ & $0.76(\mathrm{~h})$ & $\begin{array}{l}\text { Classifying and } \\
\text { modeling }\end{array}$ & $0.53(\mathrm{~m})$ & $0.84(\mathrm{~h})$ & $0.57(\mathrm{~m})$ \\
\hline Monitoring & $0.77(\mathrm{~h})$ & $0.77(\mathrm{~h})$ & $0.75(\mathrm{~h})$ & Interpreting & $0.65(\mathrm{~m})$ & $0.77(\mathrm{~h})$ & $0.64(\mathrm{~m})$ \\
\hline $\begin{array}{l}\text { Evaluating/ } \\
\text { reflecting }\end{array}$ & $0.68(\mathrm{~m})$ & $0.70(\mathrm{~m})$ & $0.69(\mathrm{~m})$ & Applying & $0.83(\mathrm{~h})$ & $0.92(\mathrm{~h})$ & $0.84(\mathrm{~h})$ \\
\hline \multirow[t]{2}{*}{ Transferring } & $0.77(\mathrm{~h})$ & $0.81(\mathrm{~h})$ & $0.71(\mathrm{~h})$ & Comparing & $0.67(\mathrm{~m})$ & $0.81(\mathrm{~h})$ & $0.63(\mathrm{~m})$ \\
\hline & & & & Concluding & $0.89(\mathrm{~h})$ & $0.91(\mathrm{~h})$ & $0.89(\mathrm{~h})$ \\
\hline Average & $0.74(\mathrm{~h})$ & $0.78(\mathrm{~h})$ & $0.72(\mathrm{~h})$ & Average & $0.70(\mathrm{~m})$ & $0.87(\mathrm{~h})$ & $0.72(\mathrm{~h})$ \\
\hline
\end{tabular}

The results indicated that most students had good metacognitive skills with an average of $\mathrm{n}$-gain score $>0.70$. Meanwhile, increased metacognitive skills (e.g. representation ability) affected the improvement of students' conceptual understanding of chemistry. This corresponded with the result of the study conducted by Treagust, Chittleborough, \& Mamiala (2003) and Hilton \& Nichols, that chemistry was more meaningful when a multiple interconnections of chemical representations was carried out, which directly improved students' conceptual understanding. The lowest aspect of metacognitive skill observed in this study was evaluation/reflection skills with an $n$-gain score $<0.70$, since some students were still unable to reflect on their learning activity and test results. Lovett (2013) suggested that structured reflection activities were needed for encouraging students to practice metacognitive skills after working on a multilevel exam. Therefore, students should complete three activities as follows:

1. remembering exactly how they prepared for the test ("reflection");

2. thinking and creating a detailed list on the mistakes they made during the exam and why it happened ("compare"), and lastly;

3. devising a plan to prepare differently for the next exam.

After these analyses were completed, students wrote reflective notes on their conceptual understanding and learning process. Engaging in metacognitive activity, assuming there were opportunities for practice and feedback, foster students to be reflective learners. This corresponded with the results of metacognitive questionnaires that had been filled in previous trials. The results indicated that the students' metacognitive skills were developed in different categories as shown in Figure 1. 


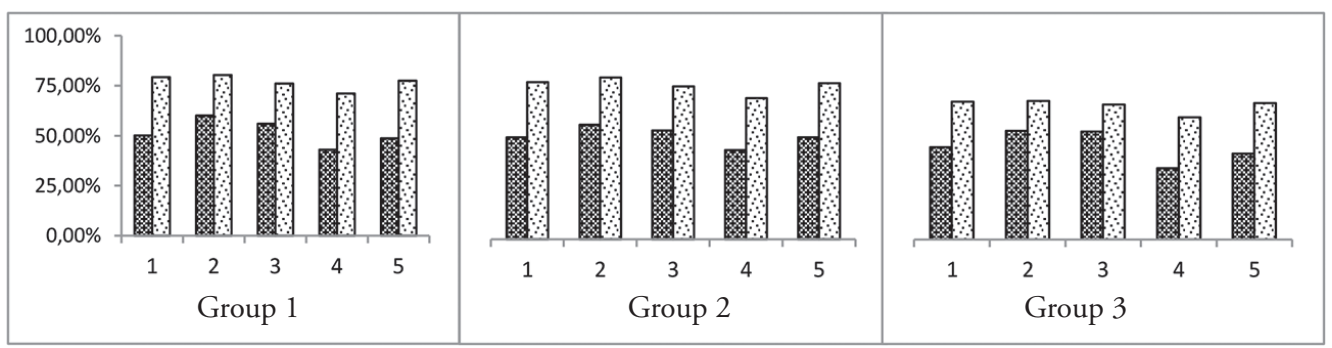

Figure 1. Students' Metacognitive and Self-Assessment before and after the i-SMART Models was Applied

Metacognitive skills were formed with habits practiced consistently; furthermore, teachers played roles in providing guidance for students, due to the wide application of the model. The results of the metacognitive self-assessment questionnaire were used as an indicator for the acquired skills, planning, representing, transferring, monitoring, and evaluating.

Based on Table 11, the i-SMART model generally increased students' conceptual understanding of the chemical equilibrium concept for groups 1,2 , and 3 , with the following $\mathrm{n}$-gain coefficients, 0.70 (moderate), 0.87 (high), and 0.72 (high). The highest $\mathrm{n}$-gain obtained were found in the aspects of explaining, classifying, modeling, applying the concepts in calculations, and concluding them in the high category. Then in comparison aspect, students compared the effect of concentration, temperature, and pressure on the direction of the equilibrium reaction in the medium category. The lowest increase was observed in the conceptual understanding, which occurred in the process of interpretation.

\section{Changes in Metacognitive Skills and Conceptual Understanding}

The students' metacognitive skills in terms of predicting: when students were faced with scientific problems, most of them predicted the answers as expected, they chose the important information from it, and made chemical representations according to the problems.

The students' metacognitive skills in terms of planning: most students prepared for the investigation to find solutions to the problems faced, they chose the relevant data from those available, they also chose the right and efficient tools for experiment and took the right steps for proper investigation.

The students' metacognitive skills in terms of monitoring: most students followed the plans that had been prepared; however, when there was another alternative for problem-solving, they merged prior knowledge with the new, and work carefully to avoid mistakes. They also changed the strategy when inconsistency was noticed, re-examine the investigation stage for consistency. The results were analysed to check for accuracy by comparing them with the previous results and tested for reliability. 
The students' metacognitive skills in terms of evaluation: most students recorded that the expected aim was achieved, meanwhile, the assessment included, the investigation, procedures, results, summary, and conclusion.

The students' metacognitive skills in terms of reflection: the reflective questions guided students in their learning process (Gama, 2004; Ge \& Land, 2004; Moon, 2004), namely, problem representation, generating solutions, making justifications, and monitoring and evaluation. These questions were asked in the assessment stage to confirm whether the learning objectives have been achieved (Pulmones, 2010). The results of the implementation of reflective activities fostered careful and in-depth thinking of the steps taken (Kauchak \& Eggen, 2013), reflective questions also had a positive influence on deeper understanding ( $\mathrm{Yu} \& \mathrm{Wu}, 2012$ ). Meanwhile, reflection is an essential part of developing students in the context of learning (Bennett, Power, Thomson, Mason, \& Bartleet, 2016). Reflection also aimed to provide feedback-corrective, which was one of the essences of mastery learning (Guskey, 2007). The factors that inhibited self-reflection were namely, low participation in reflection, lack of sufficient knowledge on the concept, and ignorant of the benefits (Aronson, 2011).

The students' metacognitive skills in terms of transferring their acquired understanding and skills to new problems. Meanwhile, feedback-corrective was one of the essences of mastery learning (Guskey, 2007) for further development of students' learning ability.

The results showed that an increase in metacognitive skills led to a higher conceptual understanding and vice versa. The increase of conceptual understanding and metacognitive skills through the implementation of i-SMART on the topic of Chemical Equilibrium was classified with high n-gain category. This was based on the indicators in each aspect of conceptual understanding namely, interpreting, exemplifying, comparing, classifying, explaining, applying concepts, and concluding. The highest conceptual understanding occurred in terms of explaining, followed by classifying, exemplifying, applying concepts, and concluding/deciding aspect. While the lowest value was found in the aspect of interpretation. This occurred since interpretation was more difficult than explaining, classifying, comparing, exemplifying, and applying concepts. It was also influenced by the questions that measured the conceptual understanding of interpretation.

Students that acquired more metacognitive skills through problem-solving process had the ability to design, monitor, and control the whole learning process. They also helped and guided their colleagues in developing a conceptual understanding of chemistry, both in interpreting, giving examples, comparing, explaining, classifying, and conclusion. Therefore, through the process of problem-solving, students easily construct ideas related to the concept, chose the right strategy, became more confident and independent learners, as well as realizing the ability to meet their personal intellectual needs. Furthermore, students determined their learning strategies, compared, and shared them with their colleagues in an effort of solving the problem. This showed that students were more involved in acquiring metacognitive skills (Tan, 2004). These skills guided students in their 
learning environment in choosing strategies and improving cognition performance for future purposes. In addition, it improved Students learning capacity and their conceptual understanding of chemistry (Anderson \& Nashon, 2007).

The results showed that i-SMART learning model was effective in improving students' metacognitive skills and conceptual understanding. At the beginning of learning using i-SMART model, students needed time to adapt. Furthermore, from the second until the fifth classroom activity, they became accustomed to using the model in problem-solving. The i-SMART model's objectives were to increase students' metacognitive skills and conceptual understanding in accordance with the Becker's et al. (2013), Pernaa and Aksela (2010), and Zoller (2011) theories, which stated that chemistry is inseparable from high-level cognitive skills (HOCS) in the process of solving laboratory-based problems (Zoller \& Pushkin, 2007). HOCS adopted the use of problem-solving experience in facilitating the development of metacognitive skills for decision making. A similar opinion was expressed by Sevian \& Talanquer (2014) that the study of chemistry required the use of high-level thinking skills in solving chemistry learning problems.

\section{Conclusion and Suggestion}

Based on the scientific problems and research results, conclusions were made as follows, i-SMART learning model is effective in:

a. increasing the students' metacognitive skills with an average gain of $(\langle\mathrm{g}\rangle)>0.70$, which is classified high in the n-gain category. Therefore, the arrangement order of n-gain from high to low range value is namely, the planning $>$ representation $>$ transferring $>$ monitoring $>$ evaluating skill.

b. increasing the students' conceptual understanding with the average gain of $(<\mathrm{g}>)>0.70$, which is classified high in the n-gain category.

Suggestions: a) i-SMART learning model is recommended in teaching practice for improving metacognitive skills and conceptual understanding of chemical concepts; b) the application of i-SMART learning model in future research has the ability to develop metacognitive skills and conceptual understanding,while focusing on students' prior knowledge. Therefore, the result showed that it was difficult for students to improve their metacognitive skills in terms of interpreting the chemical concepts. 


\section{References}

Anderson, D., \& Nashon, S. (2007). Predators of knowledge construction: Interpreting students' metacognition in an amusement park physics program. Science Education, 91(2), 298-320.

Anderson, L. W., \& Krathwohl, D. W. (2001). A taxonomy for learning teaching, and assessing a revision of Bloom's taxonomy of educational objectives. New York: Longman.

Arends, R. \& Kilcher, A. (2011). Teaching for student learning becoming accomplish teacher (1st ed.). New York: Taylor \& Francis.

Arslan, H., Cigdemoglu, C., \& Moseley, C. (2012). A three-tier diagnostic test to assess pre-service teachers' misconceptions about global warming, greenhouse effect, ozone layer depletion, and acid rain. International Journal of Science Education, 34(11), 1667-1686.

Aronson, L. (2011). Twelve tips for teaching reflection at all levels of medical education. Medical Teacher, 33(3), 200-205.

Becker, N., Rasmussen, C., Sweeney, G., Wawro, M., Towns, M., \& Cole, R. (2013). Reasoning using particulate nature of matter: An example of a sociochemical norm in a university-level physical chemistry class. Chemistry Education Research and Practice, 14, 81-94.

Bennett, D., Power, A., Thomson, C., Mason, B., \& Bartleet, B. L. (2016). Reflection for learning, learning for reflection: Developing indigenous competencies in higher education. Journal of University Teaching and Learning Practice, 19(1), 8-31.

Billing, D. (2007). Teaching for transfer of core/key skills in higher education: Cognitive skills. Higher Education, 53, 483-516.

Biryukov, P. (2003). Metacognitive aspects of solving combinatorics problems. 1-9. Retrieved from: http:// www.cimt.org.uk/journal/biryukov.pdf

Blake, B. \& Pope, T. (2008). Developmental Psychology: Incorporating Piaget's and Vygotsky's theories in classrooms. Journal of Cross-Disciplinary Perspectives in Education, 1(1), 59-67.

Brown, A. L. (1987). Metacognition, executive control, self-regulation, and other more mysterious mechanisms. In F. E. Weinert \& R. Kluwe (Eds.), Metacognition, motivation, and understanding (pp. 65-116). Hillsdale: L. Erlbaum Associates.

Carey, S. (2000). Science Education as Conceptual Change. Journal of Applied Development Psychology, 21(1), 13-19.

Carolan, J., Prain, V., \& Waldrip, B. (2008). Using representations for teaching and learning in science. Teaching Science, 54, 18-23.

Chandrasegaran, A. L., Treagust, D. F., \& Waldrip, B. G. (2009). Students' dilemmas in reaction stoichiometry problem solving: Deducing the limiting reagent in chemical reactions. Chemistry Education Research and Practice, 10(1), 14-23. https://doi.org/10.1039/b901456j

Chittleborough, G., \& Treagust, D. F. (2007). The modelling ability of non-major chemistry students and their understanding of the sub-microscopic level. Chemistry Education Research and Practice, 8(3), 274-292.

Conner, L. N. (2007). Cueing metacognition to improve researching and essay writing in a final year high school biology class. Research in Science Education, 371(1), 16. 
Cooper, M. M., \& Sandi-Urena, S. (2009). Design and validation of an instrument to assess metacognitive skillfulness in chemistry problem solving. Journal of Chemical Education, 86, 240-245. https://doi.org/10.1021/ed086p240

Cooper, M. M., Sandi-Urena, S., \& Stevens, R. (2008). Reliable multi method assessment of metacognition use in chemistry problem solving. Chemistry Education Research and Practice, 9(1), 18-24.

Delvecchio, F. L. (2011). Students' use of metacognitive skills while problem solving in high school chemistry [Unpublished Master's thesis]. Kingston, Ontario, Canada: Queen's University.

Docktor, J. (2009). Development and validation of a physics problem-solving assessment rubric. Minnesota: University of Minnesota.

Efklides, A. (2011). Interactions of metacognition with motivation and affect in self-regulated learning: The MASRL model. Educational Psychologist, 46(1), 6-25.

Erskine, D. L. (2010). Effect of prompted reflection and metacognitive skill instruction on university freshmen's use of metacognition. Hawaii: Brigham Young University.

Fraenkel, J. R., Wallen, N. E., \& Hyun, H. H. (2012). How to design and evaluate research in education (8th ed.). New York: McGraw-Hill.

Fry, H., Ketteridge, S., \& Marshall, S. (2009). A handbook for teaching and learning in higher education enhancing academic practice. London: Routledge.

Gagne, R. M., Wager, W. W., Golas, K. C., \& Keller, J. M. (2005). Principle of instructional design (5 $5^{\text {th }}$ ed.). Belmont, CA: Thomson Wadsworth.

Gama, C. A. (2004). Integrating metacognition instruction in interactive learning environment. Sussex: University of Sussex.

Ge, X., \& Land, S. M. (2004). A conceptual framework for scaffolding III-structured problemsolving processes using question prompts and peer interactions. Educational Technology Research and Development, 52(2), 1042-1629.

Greenstein, L. (2012). Assessing 21st century skills: A guide to evaluating mastery and authentic learning. California: Crowin.

Griffin, P., \& Care, E. (2015). Assessment and teaching of 21st century skills methods and approach. Dordrecht: Springer.

Grotzer, T., \& Mittlefehldt, S. (2012). The role of metacognition in students' understanding and transfer of explanatory structures in science. In A. Zohar \& Y. J. Dori (Eds.), Metacognition in science education: Trends in current research (pp. 79-99). Dordrecht: Springer.

Guskey, T. R. (2007). Closing achievement gaps: Revisiting Benjamin S. Bloom's "Learning for Mastery." Journal of Advanced Academics, 19(1), 8-31.

Hartman, H. J. (2001). Developing students metacognitive knowledge and skills. In H. J. Hartman (Ed.), Metacognition in learning and instruction: Theory, research and practice (pp. 33-68). Dordrecht, The Netherlands: Kluwer Academic Publishers.

Herscovitz, O., Kaberman, Z., Saar, L., \& Dori, Y. J. (2012). The relationship between metacognition and the ability to pose questions in chemical education. In A. Zohar \& Y. J. Dori (Eds.), 
Metacognitive in science education: trends in current research (pp. 164-196). Dordrecht: Springer.

Hadjiachilleos, S., Valanides, N., \& Angeli, C. (2013). The impact of cognitive and affective aspects of cognitive conflict on learners' conceptual change about floating and sinking, Research in Science \& Technological Education, 31(2), 133-152.

Howard, B. C., McGee, S., Shia, R., \& Hong, N. S. (2000, April ). Metacognitive self-regulation and problem-solving: Expanding the theory base through factor aalysis. Paper presented at the American Educational Research Association. New Orleans, LA.

HJacobse, A. E., \& Harskamp, E. G. (2012). Towards efficient measurement of metacognition in mathematical problem solving. Metacognition and Learning, 7, 133-149. https:/doi. org/10.1007/s11409-012-9088-x

Java, L.A. (2014). Problem solving strategies and metacognitive skills for gifted students in middle school. [Master Thesis]. Philippines: Louisiana State University.

Kaberman, Z., \& Dori, Y. J. (2009). Metacognition in chemical education: Question posing in the case-based computerized learning environment. Instructional Science, 37, 403-436.

Kang, H., Scharmann, L. C., Kang, S., \& Noh, T. (2010). Cognitive conflict and situational interest as factors influencing conceptual change. International Journal of Environmental and Science Education, 5(4), 383-405.

Kapa, E. (2002). A metacognitive support during the process of problem solving in a computerized environment. Educational Studies in Mathematics, 47, 317-336.

Kauchak, D., \& Eggen, P. (2013). Educational psychology: windows on classrooms (9th ed.). New Jersey: Pearson.

Kramarski, B., \& Zeichner, O. (2001). Using technology to enhance mathematical reasoning: Effects of feedback and self-regulation learning. Educational Media International, 38, 77-83.

Kuhn, D. (2000). Metacognitive development. Current Directions in Psychological Science, 9 , 178-181.

Lovett, M. C. (2013). Making exams worth more than the grade. In M. Kaplan, N. Sliver, D. LaVaque-Manty, \& D. Meizlish (Eds.), Using reflection and metacognition to improve student learning: Across the disciplines, across the academy (pp. 18-48). Sterling, VA: Stylus.

Mac Gregor, D. (2007). Developing thinking developing learning: A guide to thinking skill in education. New York: McGraw Hill.

Mevarech, Z., \& Fridkin, S. (2006). The effects of IMPROVE on mathematical knowledge, mathematical reasoning and metacognition. Springer: Metacognition Learning, 1, 85-97.

Moon, J. A. (2004). A Handbook of reflective an experimental learning: theory and Practice. London: RoutledgeFalmer.

Moreno, R. (2010). Educational Psychology. New York: John Wiley \& Sons, Inc.

Muna, K, Sanjaya, R E, Syahmani, \& Bakti, I. (2017). Metacognitive skills and students' motivation toward chemical equilibrium problem solving ability: a correlational study on students of XI IPA SMAN 2 Banjarmasin. In Development of Chemical Education in 21st Century Learning. Proceedings of AIP Conference, 1911, 020008-1-020008-7. https://doi.org/10.1063/1.5016001 
Nahum, T. L., Mamlok-Naaman, R., Hofstein, A., \& Taber, K. S. (2010). Teaching and learning the concept of chemical bonding. Studies in Science Education, 46(2), 179-207. https://doi. org/10.1080/03057267. 2010.504548

Osman, M. E., \& Hannafin, M. J. (1994). Effects of advance questioning and prior knowledge on science learning. Journal of Educational Research, 88(1), 5-14.

Panaoura, R., Gagatsis, A., \& Demetriou, A. (2009). An intervention to the metacognitive performance: self-regulation in mathematics and mathematics modeling. Acta Didactica Universitatis Comenianae Mathematics, (9), 63-69.

Pernaa, J., \& Aksela, M. (2010). Future chemistry teachers use knowledge dimensions and highorder cognitive skills (HOCS) in their pre-laboratory concept maps. In J. Sánchez, A. J. Cãnas, \& J. Novak (Eds.), Concept maps: making learning meaningful. Proceedings of the Fourth International Conference on Concept Mapping (pp. 137-140). Chile: Viña del Mar.

Polya, G. (2004). How to solve it. A new aspect of mathematical method. New Jersey: Princeton University Press.

Posner, G. J., Strike, K. A., Hewson, P. W., \& Gertzog, W. A. (1982). Accommodation of a scientific conception: Towards a theory of a conceptual change, Science Education, 66(2), 211-227.

Pulmones, R. (2010). Learning chemistry in metacognitive environment. The Asia PacificEducation Researcher, 16(2), 165-183.

Rain, V., \& Tytler, R. (2013). Representing and learning in science. In R. Tytler, V. Prain, P. Hubber, \& B. Waldrip (Eds.), Constructing representations to learn in science (pp. 1-14). https://doi. org/10.1007/978-94-6209-203-7

Rickey, D., \& Stacy, A. M. (2000). The role of metacognition in learning chemistry. Journal of Chemical Education, 77(7), 915-920.

Sandi-Urena, S., Cooper, M. M., \& Stevens, R. H. (2011). Enhancement of metacognition use and awareness by means of a collaborative treatment. International Journal of Science Education, 33(3), 323-340.

Sanjaya, R. E, Muna, K, Suharto, B., \& Syahmani. (2017). Self-directed questions to improve students' ability in solving chemical problems. In Development of Chemical Education in 21st Century Learning. Proceedings of AIP Conference, 1911, 020009-1-020009-6. https://doi. org/10.1063/1.5016002

Santrock, J.W. (2011). Educational Psychology; 5th Edition. New York: McGraw-Hill.

Schraw, G., \& Dennison, R. S. (1994). Assessing metacognitive awareness. Contemporary Educational Psychology, 19(4), 460-475.

Sevian, H., \& Talanquer, V. (2014). Rethinking chemistry: A learning progression on chemical thinking. Chemistry Education Research and Practice, 15, 10-23.

She, H. C. (2002). Concepts of a higher hierarchical level require more dual situated learning events for conceptual change: A study of air pressure and buoyancy. International Journal of Science Education, 24(9), 981-996.

Sousa, D. de. (2012). How the Brain Learns (4th ed.). Jakarta: PT Indeks. 
Syahmani, Irhasyuarna, Y., \& Kusasi, M. (2013). Analisis kebutuhan bahan ajar dan asesmen pembelajaran kimia yang melatih kemampuan metakognisi dalam pemecahan masalah kimia SMA kelas I semester I. [The analysis of teaching material needs and assessment of chemistry learning that trains metacognition skills in solving problems of learning chemistry in high school grade I semester I.]. Jurnal Vidya Karya, 27(3), 325-340.

Syahmani, Suyono, \& Imam-Supardi, Z. (2017). Validity of i-SMART learning model: An innovative learning to improve students' metacognitive skills and understanding of chemistry. Proceedings of 2 nd International Conference on Learning Innovation and Quality Education (ICLIQE, 2017), Surakarta, 283-296.

Syahmani \& Amini, A. R. (2019). Self-regulated learning (SRL) model with mind map to improve student cognition, and metacognition skills in solving chemical problem. JPPS (Jurnal Penelitian Pendidikan Sains), 8(2), 1690-1698.

Taasoobshirazi, G., \& Farley, J. (2013). Construct validation of the physics metacognition inventory. International Journal of Science Education, 35(3), 447-459.

Talanquer, V. (2011). Macro, submicro, and symbolic: The many faces of the chemistry "triplet." International Journal of Science Education, 33(2), 179-195.

Tan, O.-S. (2004). Enhanching thinking problem based learning approached. Singapore: Thomson. Taylor, L. K., Alber, S. R., \& Walker, D. W. (2002). The comparative effects of a modified selfquestioning strategy and story mapping on the reading comprehension of elementary students with learning disabilities. Journal of Behavioral Education, 11(2), 69-87.

Thomas, G. P., \& McRobbie, C. J. (2001). Using a metaphor for learning to improve students' metacognition in the chemistry classroom. Journal of Research in Science Teaching, 38(2), 222-259.

Thomas, G. P. (2013). Changing the metacognitive orientation of a classroom environment to stimulate metacognitive reflection regarding the nature of physics learning. International Journal of Science Education, 35(7), 1183-1207.

Treagust, D. F., Chittleborough, G., \& Mamiala, T. L. (2003). The role of submicroscopic and symbolic representations in chemical explanations. International Journal of Science Education, 25, 1353-1368.

Wang, C. Y. (2015). Scaffolding middle school students' construction of scientific explanations: Comparing a cognitive versus a metacognitive evaluation approach. International Journal of Science Education, 37(2), 237-271.

Whitebread, D., Coltman, P., Pasternak, D. P., Sangster, C., Grau, V., Bingham, S., Demetriou, D. (2009). The development of two observational tools for assessing metacognition and selfregulated learning in young children. Metacognition and Learning, 4(1), 63-85.

Yu, F. Y., \& Wu, C. P. (2012). Student question-generation: The learning processes involved and their relationships with students' perceived value. Journal of Research in Education Sciences, 57(4), 135-162. 
Yu, F. Y., Tsai, H. C., \& Wu, H. L. (2013). Effects of online procedural scaffolds and the timing of scaffolding provision on elementary Taiwanese students' question-generation in a science class. Australasian Journal of Educational Technology, 29(3), 416-433.

Zhou, G. (2010). Conceptual change in science: A process of argumentation. Eurasia Journal of Mathematics, Science \& Technology Education, 6(2), 101-110.

Zoller, U. (2011). From teaching-to-know-to-learning-to-think for sustainability: What should it take? And how to do it? Journal of Modern Education Review, 1(1), 34-40.

Zoller, U., \& Pushkin, D. (2007). Matching Higher-Order Cognitive Skills (HOCS) promotion goals with problem-based laboratory practice in a freshman organic chemistry course. Chemistry Education Research and Practice, 8(2), 153-171.

\title{
„i-SMART“ mokymosi modelio veiksmingumas naudojant chemijos dalyko mokymosi problemų sprendimo būdus vidurinès mokyklos vyresnèse klasėse, siekiant patobulinti meta-kognityvinius igūdžius ir mokinių konceptualų supratimą
}

\author{
Syahmani $^{1}$, Suyono ${ }^{2}$, Z. A. Imam Supardi ${ }^{3}$
}

Lambung Mangkurat universitetas, Jalan Brigjen H. Hasan Basry Banjarmasin, Pietų Borneo, Indonezija, syahmani_kimia@ulm.ac.id

Surabajos valstybinis universitetas, Jalan Lidah Wetan, Surabaja, Rytų Java, Indonezija, suyono@unesa.ac.id

Surabajos valstybinis universitetas, Jalan Lidah Wetan, Surabaja, Rytų Java, Indonezija, zainularifin@unesa.ac.id

\section{Santrauka}

Pagrindinè besivystančių šalių, tokių kaip Indonezija, švietimo sistemos problema yra silpni mokinių meta-kognityviniai igūdžiai ir prastas chemijos dalyko supratimas. „i-SMART“ (problemų identifikavimo ir atvaizdavimo, strategijų ir planų parinkimo, sprendimų prièmimo naudojant monitoringo sistemas, analizavimo ir ịvertinimo, apmąstymo bei perteikimo) mokymosi modelis apima meta-pažinimo naudojimą sprendžiant chemijos dalyko mokymosi problemas. Straipsnyje siekiama ištirti „i-SMART“ modelio efektyvumą mokinių meta-kognityvinių igūdžių ir konceptualaus supratimo gerinimui. Tyrimas buvo atliktas skirtingų mokyklų trijose klasėse (Banjarmasino mieste Indonezije), kuriose buvo po 30 vyresniųjų klasių mokinių. Buvo taikyti preliminarūs ir pakartotiniai testai siekiant nustatyti kiekvienos klasės (grupès) žinių ir igūdžių lygi. Surinkti testų, stebejjimo ir klausimyno duomenys analizuojami taikant n-pasiekimų (angl. n-gain), porinị t (angl. paired t), Wilcoxon'o pažymètų rangų (angl. signed-rank) ir Kruskal'ioWallis'o testus. Remiantis gautais rezultatais: 1) mokinių meta-kognityviniai igūdžiai statistiškai 
reikšmingai padidèjo n-pasiekimų dydžiu ir priskiriami prie aukštų; 2) taip pat, statistiškai reikšmingai išaugo mokinių konceptualaus supratimo n-pasiekimų dydis, kuris pasiekẻ aukštą ịvertinimą n-pasiekimų kategorijoje. Daroma išvada, kad sukurtas ,i-SMART“ mokymosi modelis yra efektyvus tobulinant meta-pažinimo iggūdžius ir studentų konceptualų supratimą.

Esminiai žodžiai: i-SMART mokymosi modelis, problemu sprendimas, meta-kognityviniai igūdžiai, konceptualus supratimas.

Gauta 20200309 / Received 09032020

Priimta 20200708 / Accepted 08072020 